\title{
ANALYSIS THE FARM-LEVEL DIVERSIFICATION AND MARKET POSITION OF THE HUNGARIAN ORGANIC PRODUCTS
}

\author{
Kinga Nagyné Pércsi', Virág Szabó \\ ${ }^{(1)}$ associate professor, ${ }^{(2)} \mathrm{PhD}$ student \\ Faculty of Economics and Social Sciences, Szent István University \\ E-mail:nagyne.percsi.kinga@gtk.szie.hu, szabo.virag@gtk.szie.hu
}

\begin{abstract}
In Hungary 1560 farms were involved in the organic farming in 2012. According to the producers' list of the Hungarian Federation of Associations for Organic Farming, on which 1126 members were registered, Pest, Szabolcs-Szatmár-Bereg, Hajdú-Bihar and Bács-Kiskun counties counts most of the organic farmers. The supply of the organic farmers can be featured by various, diversified products. The rate of the cereals determines their activities in $85 \%$, this is followed by the fruits and the products made from them, which was characteristic in $70 \%$ for their profile, the vegetables has a share of $45 \%$. The rate of the animal husbandry is only $25 \%$. The results of the questionnaire survey showed that the obstructive factor of the domestic sale is the lack of the solvent demand, marketing and the producer cooperation, and the high price in the national economic circumstances. In addition, they emphasized that the foreigners trust better in their producers and the local market organization is stronger as well than in Hungary.
\end{abstract}

Key words: cereal, fruit and vegetable, animal keeping, local market, export JEL classification: Q19

\section{Introduction}

The support of the agricultural activities is a substantial part of the rural development strategies and the land developing conceptions leaning on the excellent environmental facilities of Hungary. The domestic various flora and fauna getting narrower. In terms of the sustainable agriculture and the biodiversity these kind of producing technologies, procedures gain a new meaning. The alternative agriculture demands another approach as compared to the conventional mass production from the part of the consumers and the producers. The article focuses on the situation of the farmers in the alternative agriculture especially in the organic agriculture and on the future of the approximately 1600 farms.

\section{Review of the related literature}

The integration of agriculture and the natural environment not only means using of environment-friendly technologies but also that agriculture relies more on the ecological conditions. Thus agriculture can contribute to the prosperity and well-being of the society a great extent. One of the integration efforts is the organic farming (Villányi et al., 2000). In this approach the local and regional communities realize their specific, natural facilities and traditions of the production again. This kind of capabilities can be the key of the revitalization of the regions (Káposzta, 2011).

While the appreciation of organic food has grown in Hungary, strangely the number of companies dealing with the production of organic food has fallen. Although there was an 
increase in organic farming in the past, there has been a steady decline in the last couple of years in the volume of land used for such growing method.

"The economic motivation becomes dominant at the farmers decision making process as the farm size increases. The main aim of bigger farms is getting profit from the organic farming while the motivation of the smaller ones is the protection of the environment, and the production of healthy food" (Szarka Gáborné, 2007). This is a fact that in a normal way the farms producing organic articles get extra profit because the consumers pay higher prices for the organic products as compared to the conventional articles, this higher price is called organic premium. This premium is influenced by the followings: domestic or foreign market and demand-supply conditions. "The agricultural economists search for the options, which can provide development opportunity for the small- and medium-scale enterprises. The organic farming is an option, but only in that case if the change of the parameters influencing the organic premium is taken into account in the process of time" (Járási, 2005).

According to Roszík Péter, the managing director of Biokontroll Hungária, the reason subvention is needed, is that during the changing period, the farmer already uses bio methods, with the higher costs and higher risks, but its products do not qualify as organic yet, so no higher price can be set. The growth of the organic food stopped in the last few years. The former leap was supported by the subsidies addressed the organic farmers which were running out in the meantime so the new applicants decreased. The new entrants can count only on their own power and efforts. This is not a simple task: during the transition years the costs are raising continuously. The hoped extra profit can be achieved only later, the farmers must be wait until they receive the organic label from the strict controllers (Roszík, 2009).

The reason for the relatively low percentage of people using organic is the financial aspect. While in the rest of Europe organic food averagely costs $30-35 \%$ more than regular food, Hungary it can be up to $60 \%$ more expensive. As Gábor Czeller, the president of Hungarian Federation of Associations for Organic Farming puts it, since the people buying these products, are willing to pay almost any amount for the product considered healthier, no one is "foolish" enough to generate a price war. The domestic demand grows at a very slow pace. The farmers produce only small quantities with high costs because of the lack of coordination and integration. The main part of the Hungarian organic food is exported to abroad as a raw material $(80-90 \%)$. This is one of the reason for that the food retail chains offer import organic food.

According to Kürthy (2002) some organic farmers have not export opportunity. Rather the bigger farms are suitable for export trading. Only the bigger farms have independent export. The others export through integrating organizations. The buying of the food processing plants and the wholesalers are also considerable. The share of the retailers has not been considerable yet. The small farms sell their products toward the organic markets and small stores. The Hungarian costumers buy the half of the total marketed organic food in stores. $25 \%$ of the organic food is bought in small or specialized organic stores, the remaining part of the organic food are purchased from organic markets, farmers and from others indirect channels for example wellness hotels or restaurants (Roszík, 2011).

The three main channels of the sales are:

- organic stores,

- direct marketing of the farmers,

- sales in the retail store chains. 
Every bigger town has organic market nowadays, or there is an organic corner on the conventional town market. There are three well-known and big organic markets in Budapest, where the customers can purchase fresh organic food (Mezei-Pap, 2005). In connection with the price of the organic product we must talk about a domestic price which gets away from the reality in the most cases and which is characteristic for the organic market of Budapest. It can be perceived that the capital grew out of the organic market place. That is why the sellers who sell their products in the neighbourhood of the organic market created their own higher level of prices. This is only good for the organic farmers but is not in the interest of the consumers and the organic movement. The prices which is sometimes three-times higher here than the prices of the conventional products are unreal (Roszík, 2007).

In the last few years in the „European leader organic countries” the consumption has grown with $20-30 \%$. Although the Hungarian growing lag behind of it, but the rate of the people who decide to buy healthier food has increased with $10 \%$. The rate of the organic products within the Hungarian consumption is just $0,5 \%$, so there is plenty of space for improvement (Agroland, 2008). The yearly domestic marketing of the organic food is 20-25 billion HUF according to the estimation of Biopont Ltd., most of the costumers are mothers of age between 25 and $40.75 \%$ of Hungarians do not consume organic products at all. Only $31 \%$ of people buy organic food on a weekly basis. Organic products are generally bought for the protection of our and our children's health. $51 \%$ of organic food consumers claim to buy because of their healthy lifestyle, $26 \%$ for the health of their children, and $9 \%$ for the benefit of the environment. Hungary is the most "children centered" (26\%) in Europe with the average of $16 \%$. "Most of the super- and hypermarkets sell organic food, mainly bakery and dairy products, flour, egg, but sometimes also vegetables and fruits" (Mezei-Pap, 2005).

There is demand for the organic products in the western markets (Szarka Gáborné, 2007). Most part of the domestic production gets into export, but (for the sake of) for long-term security the domestic market must be improved (Pummer-Marselek, 2004). The aim is that the organic stands are evolved also in Hungary. A certain circle of the customer can afford to buy these products however only in small proportion. The buying power of the majority of the customers is small compared to the high price of the organic products. The market and the chain of the stores are not organized in country level. There is no organized sales in the local markets. Adequate quantity and rhytmical supply of the organic product are needed for the organized sales of organic products. This only can be achieved by the co-operation of farmers at least in the field of marketing (Szarka Gáborné, 2007).

"Roszík also mentioned as a problem that the export is outstandingly high its proportion is above $80 \%$ and the level of processing of the products is low" (Hájos et al., 2011). "Many similarities come forward when we analyse the organic sector of the neighbouring countries. The export of the high proportion of products with low added value and low level of processing makes the participant worried (for example Ukraine, Romania, Hungary, Czech Republic). The connected administrative burdens seem extremely heavy in many cases and the infrastructure of the marketing and the cooperation in the sector need development" (BioHolMi, 2013).

The regulation of the organic farming is in accordance with the regulation norms of the EU. The logistic system, the marketing work, the product processing and the education are a little bit underdeveloped in Hungary. To improve the unity of organic farming, the proportion of the animal products must be increased within the organic products (Pummer-Marselek, 2004). 
There are four areas where the organic farming lags behind in Hungary:

1. The first is the lack of supply and sale cooperations.

2. The second is the low volume of the organic animal keeping

3. The third is the lack of developed common marketing.

4. The fourth problem is that the proportion of the processed product does not approach the level evolved in the old member states of the EU.

This last one can be explained by the narrow development sources/means and by that it is not easy to access to the subsidies and loans. Taking subcontractors into the shaping of the supply chain can be a solution. There are many goods cooperation for years, which might have advantages for both participants. The free capacity of the processor can be engaged and the organic farmer can place more processed products in the market (Roszík, 2008).

Naturally the subcontractors must be involved into the controlling system of the organic farming, which means costs. Sometimes the costs exceed the profit, which can be available from the sale of the more processed products. So it is important that the services of a subcontractor would be used by more than one organic farmer. This way the emerged costs can be divided (Roszík, 2008).

\section{Methodology}

In the course of the processing of the professional literature we introduced the concept and the potential reasons for the choice of this form of farming. We used for the introduction of the organic farming the publicly available annual reports of the two Hungarian controlling and certifying organizations which can be found on the websites of these organizations. Among the results showed in the next chapter. We systematized and grouped the information which can be found in the producers' list published on the homepage of the Hungarian Federation of Associations for Organic Farming at first. The list contains 1126 farms altogether. On the basis of the data we illustrated the farms on a map spatially and determined the type of the producers' activity. We compared the gained results with the data of the professional literature. After this we presented the results of our survey, which was made among the farmers controlled by the Hungaria Öko Garancia Ltd. After the introduction of the farmers we proceeded the answers given for the questions relating to the domestic and foreign marketing. 


\section{Results and discussion}

The spatial situation and activity of the organic farmers

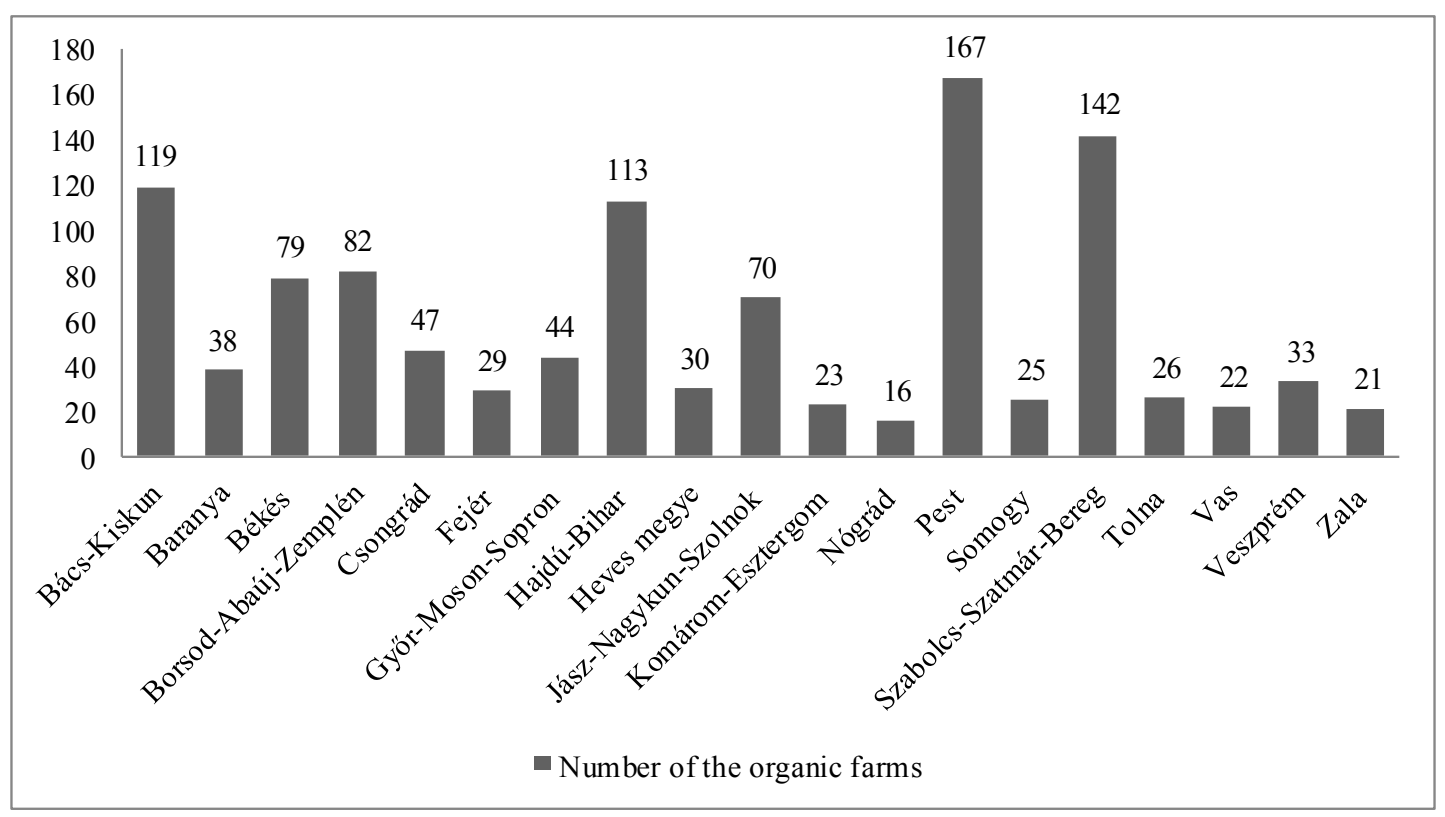

Figure 1: The number of the organic farms in the counties of Hungary, 2012

Source: Own calculation on the basis of the producers' list of the Hungarian Federation of Associations for Organic Farming, 2013

The determination of the spatial situation of the organic farms is a hard challenge, since the database of the certifying bodies is not public in this concern. However the national producers' list of the Hungarian Federation of Associations for Organic Farming is available, which is publicly available to help the marketing of the organic products and to make communication possible with the producers listed in this mailing list (the website of the Hungarian Federation of Associations for Organic Farming). We used the data published here in our analysis.

The list of producers renewed in the beginning of March 2013 contains 1126 farmers, which is $72 \%$ of the 1560 farms controlled by both organisations. The spatial distribution of the producers is demonstrated on Figure 1. On the basis of this we can state that the number of organic farmers is the lowest in Nógrád county, since there are only 16 enterprises registered on the list from this county. Most registered farms can be found in Pest county with 167 enterprises. On the basis of the data Borsod-Abaúj-Zemplén, Jász-Nagykun-Szolnok, and Békés counties register more farmers than the average, however most of the farmers concentrated in Hajdú-Bihar, Bács-Kiskun, Szabolcs-Szatmár-Bereg, and Pest counties. In the western parts of the country the number of the organic producers is under the average in every county.

On the basis of the products recorded on the producers' list the farms have the following producing profiles. There is no spatially determinant activity in any of the counties, the activity of the farmers is various and multiple in every part of the country.

- cereals and products from cereals in $85 \%$ (for example wheat, spring wheat, spelt, sorghum, buckwheat, oats)

- fruits and fruit products in 70\% (for example apple, cherry, pear, apricot, sour cherry, dried fruits, fibrous juice, preserved fruit, jams) 
- vegetables and vegetable products in $45 \%$ (for example seasoning paprika, potato, onion, sweat corn, leavened, acetic, frozen products)

- grapes and grape products in 40\% (vine, must, oil of grape seed, flour of grape seed)

- forage in $38 \%$ (alfalfa, peas and grass for feed)

- use of lawn in $28 \%$

- products from the animal keeping and products with animal origin in $25 \%$ (hen, mangalitza, buffalo, sheep, cheese)

- collecting of wild herb and the products made from this in $20 \%$

- planting of oily plants (sunflower, rape) in $15 \%$

- production of body care, cosmetic products in $15 \%$

- planting of seeds in $4,5 \%$.

Before the analysis it should be remarked that it is very hard to work with the current database because there are not a uniformly determined categories for the products, so the producers can not be selected by the plants grown, animals kept or for the products. After the systematization of the single products the following results were born.

According to the data of Biokontroll there is arable plant growing on the $32,77 \%$ of the organic agricultural areas, altogether on $38.999,4$ ha, however $85 \%$ of the farms are involved in the cereal production as commodity producer or as end product producer (bread producer). In the most cases the arable plant growing means raw material production. $42,78 \%$ of the lands certified by the Biokontroll is used for meadow, pasture and extensive lawn management. Hardy annuals were grown on $2,6 \%$, fresh vegetables, melon and strawberry were grown on $1,51 \%$. The remaining areas are used for fallow.

90\% of the total area certified by Hungária Öko Garancia was used for arable plant growing, this means 10573,57 ha. On $62 \%$ of this area cereals were grown, on $13 \%$ green harvested forage plants, on $13 \%$ pulses and protein plants, on $11 \%$ oily plants, on the remaining area different herbs and root plants are grown.

The following category, the fruits and the fruit products, is characteristic for $70 \%$ of the farms. This proportion is outstandingly high, former analysis did not report so high rate for fruit production and processing. This was followed by the proportion of the vegetables, which was grown or processed in some form by approximately $45 \%$ of the farms. According to the professional literature the demand for the organic vegetables is higher than the supply so the increase of this proportion is reasonable. The proportion of the grapes is prominently high, 434 farms out of 1126 grew grapes, $40 \%$ of these farms are registered as wine grapes producers. We find here among others Kékfrankos, Merlot, or Pinot Noir wines.

$38 \%$ of the farms grew forage, which means that not every animal keeping farm can provide the needed feed basis alone so the farmers supposedly cooperate in this field. This kind of cooperation can be a favourable prerequisite for the improvement in the number of the animal keeping farms. $28 \%$ of the farms have lawn management. This is astonishingly low as compared to that $42,78 \%$ of the certified organic area is meadow, pasture and extensive lawn according to the data published by the Biokontroll Hungária. This number reflects that the proportion of the organic lawn is high, but this sector is really concentrated at the same time.

The data underpin the statements of the professional literature processed according to which the proportion of the animal keeping farms is really too low. However it should be mentioned that on the basis of the data of Biokontroll Hungária from 2012 the proportion of the animal 
keeping farms is only 5,5\%, but it possible that only those farms were counted in which keeping only animals as a single activity. According to the above mentioned data $25 \%$ of the farmers keep some kind of animals or produce different kind of animal products. However this proportion is really low, it gives a better picture as compared to the data of the Biokontroll.

It is interesting that the proportion of the wild grown herbs and the production of cosmetics are relatively high. It is characteristic for $20 \%$ and $15 \%$ of the farms respectively. This shows that the demand for the products made from natural raw materials and herbs is growing steadily. $15 \%$ of the farms grow oily plants, which can be considered low regarding the need of the body care sector. Referring to the words of Péter Roszík, the proportion of the organic seed growing is really very low, only $4,5 \%$. Respecting the high proportion of the cereals, higher proportion of the seed growing should be reasonable without this the sector needs procurement of import input raw material.

\section{The results of the survey}

The other problematic area mentioned by Roszík the high rate of the export which was assessed by us with a survey in March 2013. We sent the questionnaires to the producers certified by the Hungária Öko Garancia with the support of the certifying body. We split the questionnaire into more parts. We surveyed the general characteristic of farming at first, then we asked questions relating to the marketing. In 201239 sent back the questionnaire from the 102 farmers involved in the production, which is $38 \%$.

Regarding the situation of the farmers it can be stated that most of them originated from the Middle Hungarian and the South Plain Regions. On the basis of the producers' list published by the Hungarian Federation of Associations for Organic Farming, the South Plain Region accounts for 245 producers from the 1126, Pest county has 167 enterprises. Only one answer arrived from the North Plain Region which registers the most, 325 farmers. This is really scarce. Regarding the other regions the number of the responders is between 3 and 6 , so the answers of the farmers from the Middle Hungarian and the South Plain Regions dominate in 51\%. It should be remarked that their predominance is reasonable because of the existence of the bigger producers' basis.

$50 \%$ of the responders deals with cereal growing, $44,7 \%$ deals with vegetable growing, $38,5 \%$ occupies with fruit producing, $18.4 \%$ is interested in animal keeping. The cereal growing has the highest proportion among the farms in alignment with the list of the Hungarian Federation of Associations for Organic Farming, the proportion of the vegetable growing almost corresponds with the data in the list, but there are only few fruit producing farms surveyed.

The proportion of the animal keeping farms stays under $25 \%$, but it is fortunate that so many producers involved in animal husbandry responded to our questions. Beside this such organics got in the sample as: home-made syrup, jam, vegetable products, cheese, apple juice, condensed apple juice, condensed elderberry juice, white paddy, herbs (fresh, dried, grown, collected), dried woody mushrooms, pickle, egg, husked products (panic-grass, buckwheat, sunflower), extruded oil of vegetable marrow seed, plum jam, oil of walnut, stewed prunes, hay of alfalfa (conversion, conventional), seed producing (mustard, peas, vetch), producing of oil marrow, pollen, oyster mushroom, herbs plants, vegetable plant, container bedding plant, products of milling industry, bread, baked goods, products of canning industry, house leek, almond, herbs: lemon grass, peppermint, fennel, milfoil, nut meat, and nutshell. 
It is obvious from the list above, that this small sample has a very various and wide range of products. This variegation is characteristic for the national organic production also. Regarding the range of size in case of the organic plant growing farms we can observe that the smallest land is 4 ha, while the biggest is 828 ha. The average size of the farms is 193 ha. In the case of horticulture these values are varying between 0,5 and 18 ha. The average size of the farms is 6 ha. In case of the animal unit the lowest value is 6 and the highest is 940 animal units. These values show that there are really small and also large farms among the responders.

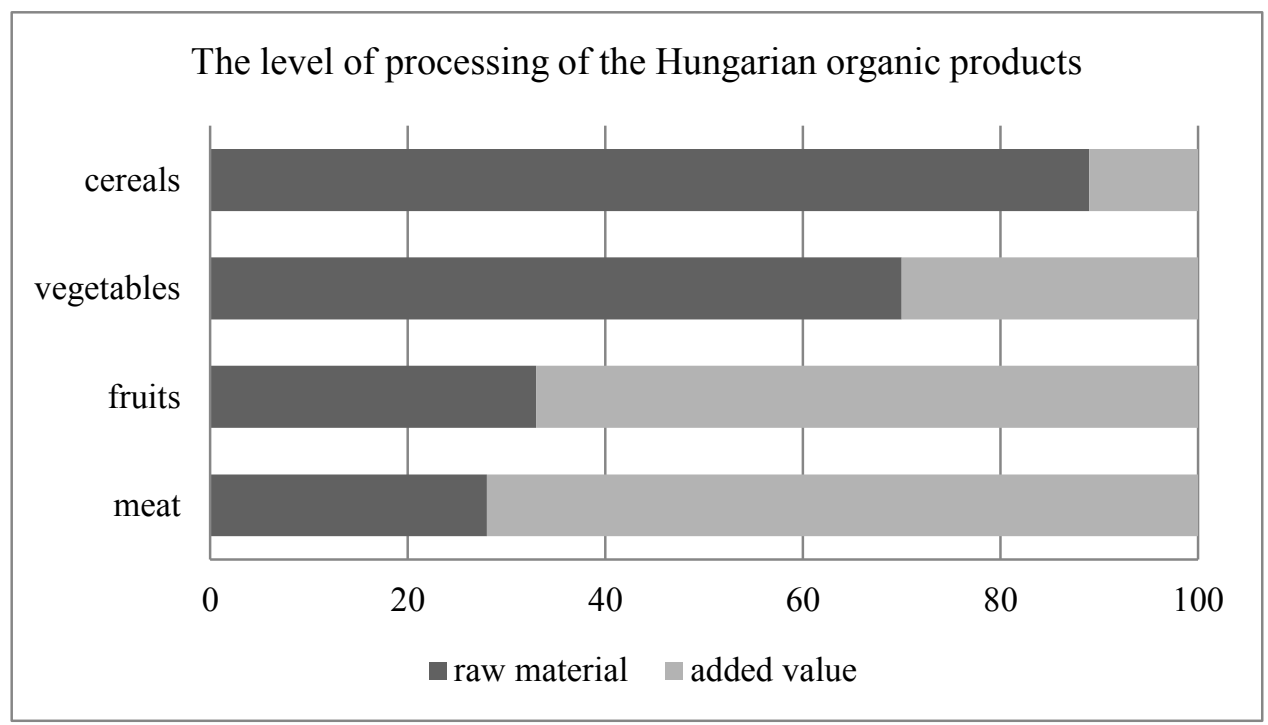

Figure 2: The level of processing of the Hungarian organic products

Source: On the basis of own research, 2013

$89 \%$ of the cereals, $70 \%$ of the vegetables, $33 \%$ of the fruits, $28 \%$ of the meat products are sold as raw material (Figure 2). The meat products contain some added value in $72 \%$ and $67 \%$ of the fruits was put on the market as processed products also. In the case of the meat and fruit it is favourable but huge amounts of cereals was sold as raw material. This is disadvantageous because this features the supply of the farmers in $85 \%$.

The cereal growing and the fruit producing farms export their products in the highest rate from the farmers got into the sample, this means 63 and $60 \%$ respectively. $43 \%$ of the meat products were sold abroad, while $41 \%$ of the vegetable producing farms export their products. However this value is under the $80 \%$ given in the professional literature it can be regarded as high.

When we asked them about the difficulties of the marketing, they gave the following answers which point out the constraints of the increasing of the internal markets. The producers see the lack of co-operation and the lack of solvent demand as the weakest points of the Hungarian organic farming (Figure 3). They regard the inadequate marketing also as a serious problem, because it weakens the consciousness of the market presence of the domestic products. The price is unreasonably high on the domestic markets, but this means a lower price difference as compared to the traditional products in foreign conditions of earnings. This is underpinned by that the lack of solvent demand can not be felt in foreign markets. 


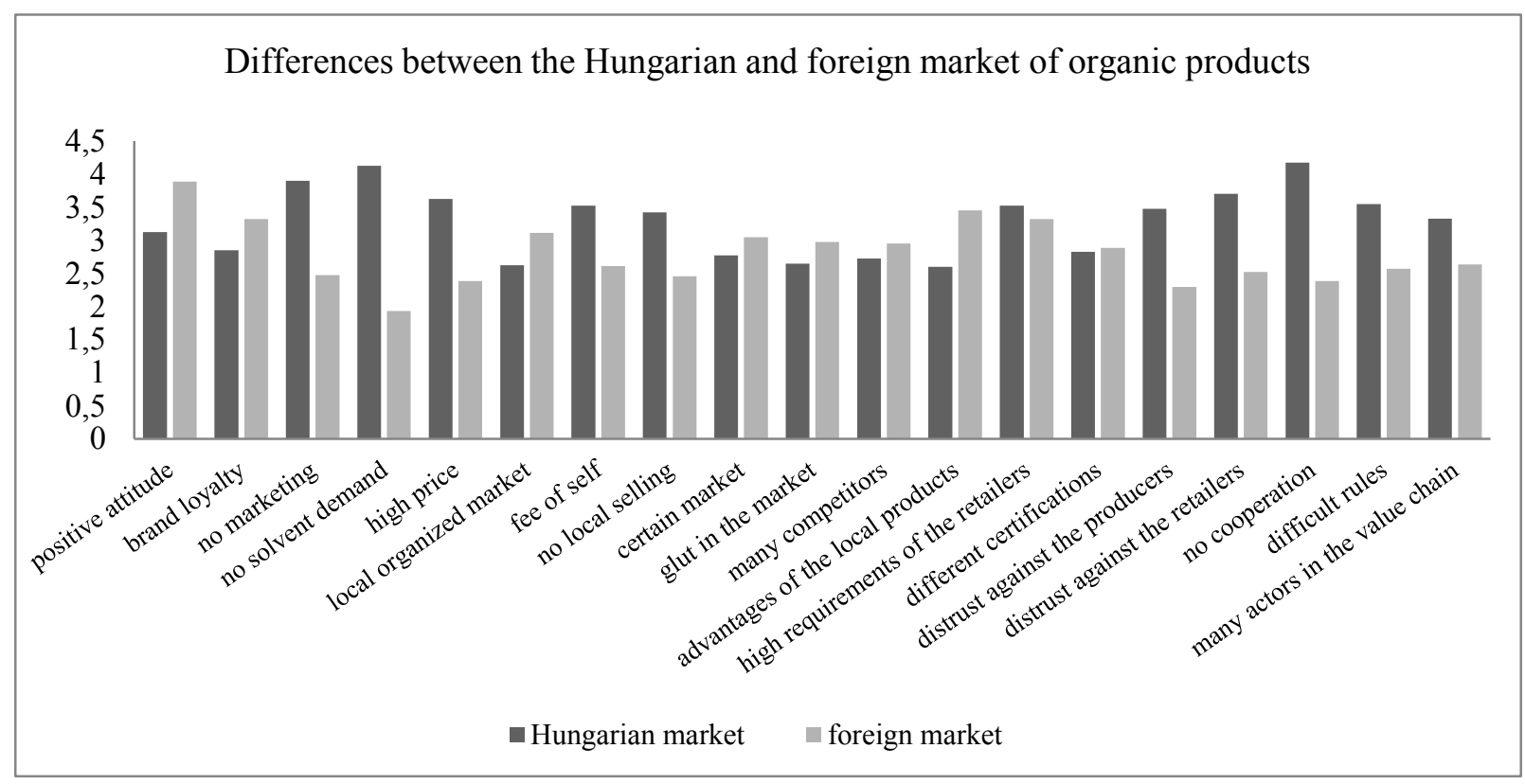

Figure 3: Differences between the Hungarian and foreign market of organic products based on the opinion of the farmers

Source: On the basis of own research, 2013

The producers find some requirements hard to meet also nowadays. They mentioned the mistrust towards the producers and retailers as a weak point. It seems the costumers trust in their own producers abroad. In connection with this it should be mentioned that there is no culture of the local marketing yet. That is why the farmers must fight for the goodwill of a retail chain, which demand high shelf fees. The attitude of the foreign costumers is much more positive than the attitude of the domestic costumers. The brand loyalty as well as the strong local market organisation is more developed at them, so they prefer the local products of course. The foreign markets also face the strengthening competition and the saturation of the markets, but they protect more their own products because of the above mentioned reasons.

\section{Conclusions}

However the state of the organic production was analysed by many studies, a systematized, standardized register of the producers is missing. This kind of a register can help to find out more about the farmers. On the basis of the currently available database and the survey it can be stated that the organic farmers have a wide range of products and there are big differences in the size of the farms. Most of the farmers grows cereals and produces products from cereals. They were followed by the fruits, vegetables and grapes producing farmers.

The proportion of the farmers dealing with grapes reaches the $40 \%$ of all farms, which is outstanding. Only $28 \%$ of the farmers is involved in the grassland management, which is surprisingly low as compared to that $50 \%$ of the agricultural lands is lawn. The proportion of the organic animal keeping is still low however on the basis of the circle of activity given by the farmers the proportion of the animal keeping and animal product producing farms can be assessed to approximately $25 \%$. However this number is unfavourable it shows a better picture than the $5 \%$ assessed on the basis of the annual report of the Biokontroll. The forage growing is characteristic for $38 \%$ of the farms, which means that more farms deal with forage growing than animal keeping, so the farmers can not produce the needed amount of feed alone in many cases. Many farmers $(20 \%)$ deals with the collecting of wild grown herbs and they produce 
different products from these. $15 \%$ produces organic cosmetics. The proportion of the seed growing farms is only $4,5 \%$, which makes the sector vulnerable.

Relating to the marketing of the organics the producers mentioned the lack of sales promotion and the co-operation as a constraints. According to the results of the survey the responders export $63 \%$ of the cereals, $60 \%$ of the fruits, $43 \%$ of the meat and $41 \%$ of the vegetables. Additionally most part of this was exported as raw material. The farmers feel that there is no co-operation, the local marketing is disorganized and they can produce profitably only at high market price in domestic conditions. The positive attitude has not been developed yet in the Hungarian costumers and the brand loyalty is also lacking. The trust toward the farmers and retailers is also insufficient, which exacerbate the problems in the domestic marketing.

\section{References}

1. BioHolMi (2013): A bioszektor helyzete Közép- és Kelet-Európában. Előadás a Biofach Kongresszuson. 2013. tavasz

2. [Downloaded: .27.04.2013]

3. Biokontroll Hungária Ltd.: Annual report, 2011.

4. Agroland (2008): Kisebb területen folyik biotermesztés. http://www.agroland.hu/?hir=3967

5. Biopont Ltd. - Roszík, P. (2011) Published by: A magyarokat nem nagyon izgatja a bioélelmiszer.http://www.piacesprofit.hu/klimablog/fenntarthato_fejlodes/a_magyaroka t_nem_nagyon_izgatja_a_bioelelmiszer/ [Downloaded: 03.10.2013]

6. Czeller, G. (2009) Published by: Organic farming declining in Hungary. http://www.green4v4.eu/content/organic-farming-declining-hungary [Downloaded: 06.08.2012]

7. Hájos L. - Bárdos B. E. - Avar. L. - Forgács T. - Hájos Cs. - Bagi O. - H. Abelovszky J.- Bedő P. - Győri A. - Hajtun Gy. - Viniczai S. - Czifra L. - Prág F. (2011): Napirenden az állattenyésztés és az ökológiai gazdálkodás. Magyar mezőgazdaság. 66 évf. 23. szám, 2011. június 8 .

8. Hungária Öko Garancia (2011): Annual report, 2011.

9. Hungarian Federation of Associations for Organic Farming: http://www.biokultura.org/index.php/ct-menu-item-2

10. Járási, É. (2005): Az ökológiai gazdálkodás, Szaktudás Kiadó Ház, Budapest, 2005. In: Szakmai füzetek. Szerk: Dr. Kovács László Miklós 7-47. p.

11. Káposzta J. (2001): Regionális gazdaságtan, Szent István Egyetem, Gazdaság- és Társadalomtudományi Kar, Regionális Gazdaságtani Tanszék, Gödöllö, 2001. 89. p.

12. Kürthy Gy. (2002): A biotermelés hazai helyzete és fejlödési lehetőségei. Gazdálkodás. XLVI. 5. 16-25. p.

13. Mezei, M. - Pap, Z. (2005): Situation of ecological agriculture in Hungary. Organic Farming in Poland as Example of Organic Farming in CEE Countries - from farm to plate", 25-29 July 2005, Warsaw and Culavia - Pomerania,

14. Pummer, R. - Marselek, S. (2004): Az ökológiai gazdálkodás lehetőségeinek elemzése. A tanulmány Az NKFP. 2004/4014-04 OM kutatási feladat keretében készült. 1-6. p.

15. Roszík, P. (2008): Bionap Balmazújvásáron. Agrárunió, IX. évfolyam, 8-9. szám, 82. p.

16. Roszík, P. (2008): Legyen jövedelmezőbb a biogazdálkodás. A Magyar Mezőgazdaság és Kertészet és Szőlészet melléklete V. évfolyam, 8. szám, 8. p. (A Biokultúra újság nyomán: 2008/3. szám, 3. oldal) 
17. Roszík, P. (2009) Published by: Jól türik a válságot a bioélelmiszerek. http://nol.hu/gazdasag/20090831-jol_turik_a_valsagot_a_bioelelmiszerek [Downloaded: 01.05.2013]

18. Szarka Gáborné (2007): A biogazdálkodás esélyei, http://www.agr.unideb.hu/4meco/?c=publikacio [Downloaded: 05.10.2008]

19. Villányi L, Tóth T, Káposzta J, Szénay L, Molnár J, Péter B, Guth L, Puskás J, Kapronczai I, Lehota J Szénay L, Villányi L (szerk.): Agrárgazdaságtan, Budapest: Szaktudás Kiadó Ház, 2000. 242 p. (ISBN:963 356319 4) 56-57. p. 